\title{
Field Evaluation of Two Aqueous Plant Extracts on Water Melon Citrullus lanatus (Thumb) Insect Pets in Northern Guinea Savannah of Nigeria
}

\author{
M. M. Degri ${ }^{1, *}$, H. S. Sharah ${ }^{2}$ \\ ${ }^{1}$ Department of Agronomy, faculty of Agriculture, Federal University Kashere, \\ PMB 0182 Gombe, Nigeria \\ ${ }^{2}$ Department of Crop Protection, University of Maiduguri, PMB 1069, Maiduguri, Nigeria \\ *E-mail address: michaelmd4peace@hotmail.com
}

\begin{abstract}
Leaf beetles and fruitfly infestation greatly limits water melon (Citrullus lanatus) production throughout the tropics. The efficacy of aqueous plant extracts applied at $5 \% \mathrm{w} / \mathrm{v}$ concentration of two botanicals (neems seed oil and garlic bulb) and 1.5 melt of one synthetic insecticide (karate 2.5 EC) against their infestation were evaluated. The effects of these treatments including control on the number of the insects, number of leaves, vines, length of vines, number of fruits, fruit weight, fruit damaged and undamaged were assessed during 2012 and 2013 cropping seasons in Lawanti, Gombe state, Northern Guinea Savannah region of Nigeria. Result of the study showed that neem seed oil and garlic bulb treatments at $5 \% \mathrm{w} / \mathrm{v}$ were effective against the leaf beetles and water melon fruitfly as the synthetic insecticide karate $2.5 \mathrm{EC}$ in managing the water melon insect pests. Karate $2.5 \mathrm{EC}$ significantly reduced the infestation of the insect pests of water melon and increased number of leaves, vines, length of vines, number of fruits, fruit weight and number of undamaged fruits/plot followed closely by neem seed oil (A. indica) and garlic bulb (A. sativum) extracts. Water melon a growth and fruit yields were appreciably improved in these treatment while untreated control water melon crops had more leafs beetles and fruitfly infestations, poor plant growth and lower fruit yields. Both botanicals can thus serve as alternatives to synthetic insecticides for managing water melon leaf beetles and fruitfly attack.
\end{abstract}

Keywords: water melon; Aqueous; plant extracts; insect pests; savannah; Fruit; synthetic insecticide

\section{INTRODUCTION}

Citrullus lanatus (Thunb) belongs to the family Cucurbitaceae and it is probably originated in Africa, the continent were most of its wild relatives and some primitive varieties can be found (Rossel and Thottappilly, 1985). It is grown almost all the tropics and subtropics of Africa, Asia and Latin America both in rainy and dry season. Water melon is predominantly warm season crops of tropical and subtropical origin, many of which thrive in hot and humid condition. It requires a warm and dry weather, good sunshine, low humidity and frost-free period. Water melon grows best and give high yield in well drained sandy 
loamy soil. Heary soil if drained well also gives good yield do not grow well in highly acidic or alkaline soil (Schippers, 2000). Water melon is essentially a creepes, herbaceous annual prostrate plant (Nath et at 2002).

Water melon plant often produce coiled branched or unbranched tendrils arising from the side of the leaf bases called vines (Ghazafar, 1989). It is mostly used as dessert and highly of economic value being a major source of sugar, water, vitamins and mineral salts (Schippers 2000). Water melon contains $7.55 \mathrm{~g}$ carbohydrate, 6.g sugars, $0 . \mathrm{g}$ fibre, $0.15 \mathrm{~g}$ fat, $0.61 \mathrm{~g}$ protein, $91.45 \mathrm{~g}$ water, $28 \mathrm{mg}$ vitamin $\mathrm{A}, 303 \mathrm{mg}$ beta carotene, $0.033 \mathrm{mg}$ thiamine (vitamin B1), $0.021 \mathrm{mg}$ Riboflavin (Vitamin B2), $0.178 \mathrm{mg}$ niacin (Vitamin B3, $0.221 \mathrm{mg}$ pantothenic acid (vitamin B5), 0.045mg Vitamin B6, $4.1 \mathrm{mg}$ choline, $8.1 \mathrm{mg}$ Vitamin C, 7.0 $\mathrm{mg}$ calcium, $0.24 \mathrm{mg}$ Iron, $10 \mathrm{mg}$ magnesium, $0.038 \mathrm{mg}$ manganese, $112 \mathrm{mg}$ potassium, 1.0 mg sodium, $0.1 \mathrm{mg}$ zinc and $4532 \mathrm{mg}$ lycopene (Nath, et al., 2002).

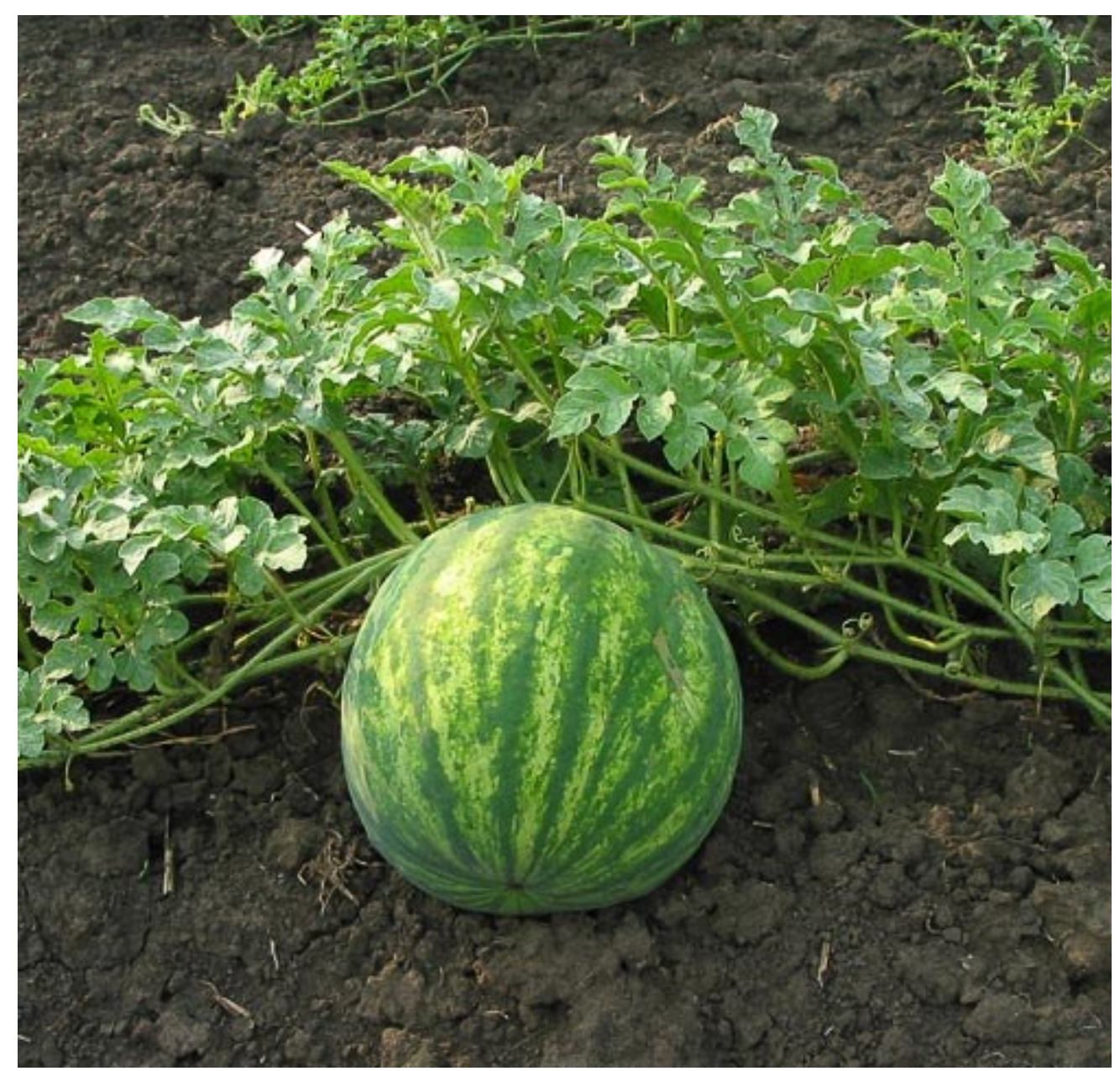

Photo 1. Citrullus lanatus.

In Nigeria water melon is grown in savannah regions such as Bauchi, Gombe, Southern Borno states where it is being used as juice, fruit salad, and dessert all-year round.

The key to water melon is lots of sugar and water which is made by leaves. So anything that hurts the leaves also hurts the quality and the quantity of the fruit (Nath, et al., 2002, http://www.uga.edu/veg/melon.html.2005). 
Among the major economic insect pest of water melon are Epilachna beetles (Epilachna chrysomelina) which cause severe damage to leaves of the melon. They feed on the green matter between the vein giving a lace like appearance to the attacked leaf. Leaf beetle (Aulacophora Africana) which attack most of the crops at seedlings stage. They feed upon the cotyledonary leaves of the seedlings causing damage by both the larvae and adult. Aphids (Aphis sp) suck the sap of the plant. They multiply very quickly and cause considerable damage when in large numbers particularly in early stage causing the leaves to turn yellow and plant loses its vigour. Jassids (Empoasca sp.) are small green to greenishyellow sucking insects which suck the sap of the leaves causing shrivelled appearance. Melon fruitfly (Dacus sp.) maggots which cause considerable amount of damage to the young fruits with loose ranging from 50-75\% (Ullah, 1997).

The melon fruit fly according to Youdeowei (2004) pierces the fruit of the cucurbit family and lay eggs between the skin of the young fruits. The eggs hatch in white maggots that feed inside the fruit causing sunken discoloured spots or patches, distortions or shrivel or rot. The fruits drop from the plant and thus the farmer obtains a very low yield (Shagufta, Alford 1984, 2012, Pareek and Kavancha, 1988, White et al., 1994). Farmers in the Northern Guinea and Sudan savannah have being growing water melon during both rainy and dry seasons apparently without any recommended insecticides of botanical origin. The study is therefore aimed at assessing these two local available plant extracts with the view of recommending the best economically and friendly plant insecticide as alternative to synthetic insecticide for melon farmers.

\section{MATERIALS AND METHODS}

Field experiment were conducted at Lawanti village located at Gombe (latitude $10^{\wedge} 0$ $15^{\wedge} 0 \mathrm{E}$ and longitude $11^{\wedge} 014 \mathrm{~N}$ at elevation of $319 \mathrm{~m}$ above sea level $12.008 \mathrm{GPS}$ ) during 2012 and 2013 rainy seasons. The soil of the area is sandy-loamy. The experimental plot was ploughed, harrowed and laid out in a complete randomized block design. Two aqueous plant extracts NSO and garlic was compared with a synthetic insecticide karate 2.5 EC replicated four times including untreated control.

The water melon seed were obtained from Gombe state Agricultural Development Program (GSADP) input store at Bogo, Gombe while the neenm seed oil (NSO) and garlic bulbs were obtained from reputable marketers in Gombe main market.

The water melon seeds were planted in August according vto the recommended cultural practices for sole cropping at $150 \mathrm{~cm} * 60 \mathrm{~cm}$ row to row and $100 \mathrm{~cm} * 120 \mathrm{~cm}$ hill to hill (5 stands per row $* 4=20$ stands $/$ plot).

The experimental plot were weeded at any time weeds appeared using hoe. The aqueous plant extracts and conventional insecticide were applied on the crops $t$ one week intervals at the rate of $5 \% \mathrm{w} / \mathrm{v}$ concentrate and $1.5 \mathrm{ml} / \mathrm{l}$ of water respectively.

Data were collected on the following parameters:

A) Number of insect pest /plant: three insect pest were counted per plant at three stages (full growth, and flowering) between 7.00-8.00 am when the insect pest have not gone into hiding. B) At full growth of the crops when they are starting fruiting, the number of vines /plant, length of vines and number of leaves/plant were counted and or measured using a plastic measuring tape in centimetres and recorded. 
C) Number and weight of water melon fruit: this was done at harvest to determine the yield of water melon fruilt in kilogram/plot. All fruit collected at harvest were counted and weighed immediately using jenway top loading balance (2000 model) scale with a capacity of $25 \mathrm{~kg}$ and the data recorded.

D) Number of damaged and undamaged water melon in kilogram/plot: all fruit damaged by insect pests and those that are healthy were sorted out from each plot, counted and weighed immediately after each harvest and recorded.

E) Number of fruit larva /plot: all damaged water melon fruit were picked at random from each plot at harvest. They were dissected and washed in clean water. The larva found insided the damaged fruits were separated from the seeds and water melon flesh by using a $0.5 \mathrm{~mm}$ severs. The larvae were counted in "in site" using a hand lens and recorded.

The data collected from the parameter were subjected to analysis of variance (ANOVA) and their individual treatment means compared using least significant difference (LSD) at 5 $\%$ level of probability.

\section{RESULTS AND DISCUSSION}

The number of insect pest recorded attacking water melon [Citrullus lanatus (thumb)] per plant during vegetative stage and fruiting stage are presented in Table 1 . The results showed that karate (lambda cyhalothrin) 2.5 EC treated plot had significantly the lowest Epilachna sp (1.43) Aulacophora sp.(1.52) and Dacus sp.(3.31) infestation followed by neem seed oil $(2.67,2.50$ and 4.53$)$ and garlic bulb $(2.73,2.97$ and 5.70$)$ treatments while untreated control plots significantly the highest $(4.23,4.10$ and 6.97). All the aqueous extract of the botanicals reduced the infestation of the beetles and fruit fly on treated water melon, the extract of neem seed oil was relatively more effective against crop infestations but not statistically different from each other were the extracts at par with the synthetic insecticide

Table 1. Effect of insecticides application on insect pest infestation. Treatment No. of insect pest/plant Epilachna sp. Aulacophora sp. Dacus sp.

\begin{tabular}{cccc} 
Garlic bulb & $\mathbf{2 . 7 3}$ & $\mathbf{2 . 9 7}$ & $\mathbf{5 . 7 0}$ \\
\hline Neem seed oil & 2.67 & 2.50 & 4.53 \\
Control (untreated) & 4.23 & 4.10 & 6.97 \\
SE+/- & 0.22 & 0.28 & 0.45 \\
LSD (0.05) & 0.54 & 0.48 & 1.10
\end{tabular}

The aqueous extracts of the two plants therefore, seem to have potent insecticidal properties for controlling the three insect pests infestation and reducing their population increase during the study period. Plant based insecticides contain compounds with properties 
that repel or disrupt the feeding, growth or reproductive activities of insect pest on crop (degri et al 2013). Azadirachtin, a triterpenoid substance from neem plant has been generally reported to have repellent, antifeedant, growth inhibitory and toxic or insecticidal activities against a number of insect pests (Debashri and Tamal, 2012, Degri et al, 2012, Degri et al, 2013). Gupta et al, (1990) reported that $1 \%$ and $3 \%$ oil emulsion spray of $A$. indica on rice respectively reduced the incidence of (Naphalocrocis medinalis and protected developing grains against Leptocorisa acuta. Neem seed oil (5\%) sprays have been reported to effectively reduced the population of Helicoverpa armigera in chichpea (Siddappaji, et al, 1986). Neem seed oil and garlic extracts at $5 \% \mathrm{w} / \mathrm{v}$ were found effective against the leaf miner in eggplant (Solamum melongena L.).

Table 2 showed that karate 2.5EC, neem seed oil and garlic extract were good in preventing insect pest infestation in water melon in the field. The attack of the leaf beetles was deterred on the treated plants by this plant extract and karate in the field. During the two years, but there was continuous infestation of the water melon in untreated control treatment. This implies that karate 2.5 EC protect the plant against the leaf feeding beetles, thus the significantly higher number of vines recorded per plant in the treated plots than the untreated control plots.

Table 2. Effect of insecticide application on number of vines per plant.

\begin{tabular}{|cc|}
\hline Treatment & No. of vines/plant \\
\hline Karate 2.5 EC & 9.50 \\
Garlic bulb & 4.42 \\
Neem seed oil & 8.33 \\
Control & 2.58 \\
SE $+/-$ & 0.40 \\
LSD $(0.05)$ & 0.82 \\
\hline
\end{tabular}

Table 3. Effect of insecticides application on length vines/plant.

Treatment

length of vines/plant (cm)

\begin{tabular}{cc}
\hline Karate 2.5 EC & 62.50 \\
Garlic bulb & 33.50 \\
Neem seed oil & 46.50 \\
Control & 26.00 \\
SE+/- & 11.09 \\
LSD $(0.05)$ & 35.31
\end{tabular}

The results of the length of vines per plant are presented in Table 3 and 4 . Similar to the above trend, the number of fruit per plot, Table 5, weight of fruit per plot (Table 6) number of 
damaged fruit and undamaged fruits/plot are presented in Table 7. The number and length of vines were significantly higher in all the treated plots than control.

Table 4. Effect of insecticides application on number of fruits/plots.

Treatment

mean number of leaves/plant

Karate 2.5 EC

11.42

Garlic bulb

9.58

Neem seed oil

10.17

Control

6.58

$\mathrm{SE}+/-$

0.53

$\operatorname{LSD}(0.05)$

1.08

Similarly the number of water melon fruits per plot, weight of fruit per plot, number of undamaged fruits were all significantly higher in the treated plot than the untreated control plots during the two years study, while the number of damaged fruits per plot were significantly lower in the treated plots than the untreated control plots.

Table 5. Effect of insecticides application on number of fruits/plot.

\begin{tabular}{|cc|}
\hline Treatment & mean no. of fruits/plant \\
\hline Karate 2.5 EC & 13.17 \\
Garlic bulb & 9.83 \\
Neem seed oil & 10.75 \\
Control & 6.67 \\
SE $+/-$ & 0.44 \\
LSD $(0.05)$ & 0.89 \\
\hline
\end{tabular}

Table 6. Effect of insecticides application on weight of fruits/plot.

\begin{tabular}{|cc|}
\hline Treatment & mean weight of fruits/plot (kg) \\
\hline Karate 2.5 EC & 65.85 \\
Garlic bulb & 49.15 \\
Neem seed oil & 53.75 \\
Control & 33.35 \\
SE $+/-$ & 2.20 \\
LSD $(0.05)$ & 4.45 \\
\hline
\end{tabular}

The overall results indicate that the higher number of vines, vine length, number of fruits, fruit weight and undamaged fruits obtained from the treated water melon plots indicate lower damage due to attack by the Epilacna and Aulacophora beetles and the melon fruit fly (dacus spp.). 
Table 7. Effect of insecticides application on weight of fruits/plot.

\begin{tabular}{|ccc|}
\hline Treatment & no. of damaged fruits/plant & no. of undamaged fruits/plot \\
\hline Karate 2.5 EC & 0.17 & 13.00 \\
Garlic bulb & 2.00 & 7.83 \\
Neem seed oil & 0.67 & 10.08 \\
Control & 3.17 & 3.50 \\
SE + - & 0.26 & 0.40 \\
LSD $(0.05)$ & 0.53 & 0.82 \\
\hline
\end{tabular}

Greater general growth and yield of water melon obtain from crops treated with both synthetic and botanical insecticides was attributed to the reduction of the insect pest infestation and feeding activities on the crops (Ghosh, 2010, Shagufta, 2012, Nath et al, 2002, Pareek and Kavancha, 1988).

Leaf beetles and fruit fly attack and feeding during the vegetative and fruiting stage of water melon often lead to retarded or stunted growth, poor or low, leaves and vines development and growth fruit, fruit abortion or premature dropping of fruits, poor fruit setting fruit shrivelling or rot ( white et al, 1994). Nath et al, 2002, Shagufta, 2012; that culminates in poor fruit setting, high fruit shrivelling or rot and decreased crop yield. The key to water melon production is the production of lots of sugar which is made by the leaves and green vines.

So therefore anything particularly pests that attack the leaves, green vines, flowers and fruits affects the quantity and quality (Babarinde et al, 2008 Ratnadass et al, 2011). As such, it is very important to protect the vegetative and reproductive structures of water melon crops with insecticide (synthetic or botanical) to avoid hurting them to aid obtain good water melon yield. Without which as in this study water melon crops may incur beetles and fruit fly infestation damage severe enough of the fruits to lead to poor crop yield (Van der vossen et al, studies have shown that spraying 2004) of insecticides (synthetic or botanical) at the vegetative and fruiting stages of water melons generally reduced insect pests infestation and flower and fruit damage, and ultimately increased the number of vines, leaves, flowers, fruits, fruit weight and fruit number thereby increasing crop yield (Ibekwe et al, 2013, Muhammad et al., 2013).

The lower number of insect pests was less on water melon treated with $A$. indica and $A$. sativum than untreated crops. The number of vines, length of vines, number of leaves, number of fruits, fruit weight and number of undamaged fruits were higher than untreated crops. Neem seed oil and garlic having performed better due to their high percentage of azadirachtin content that has a storage life varying between 3 to 8 months. Neem extracts are also effective against a large number of insect pests. Garlic (Allium sativum) is mainly repellent, antifeedant, insecticidal, nematicidal, fungicidal, bactericidal and active against many insects pests ( Pedigo, 1996).

These two botanical insecticides were found at par with the synthetic insecticide used karate 2.5 EC have proven to be effective against the insect pests infestation, and as a result found to sustain greater water melon yield. Synthetic insecticides usually posses only one or few toxic elements. It is easier for the pests to develop resistance against such insecticides.

Whereas, botanical insecticides posses a number of toxic elements in them and pests find it difficult to develop resistance against them .Botanical insecticides have also broad spectrum effect. Both botanicals can therefore serve as alternatives to synthetic insecticides 
for of the advantages of these two botanicals are readily available in the savannah region of Nigeria and they are bio-degradable, friendly or safe to the farmers and applicators, consumers and environment.

\section{CONCLUSION}

The application of the aqueous extract of $A$. indica oil and $A$. sativium from vegetative to fruiting stage at weekly intervals greatly reduced leaf beetles infestation of water melon crops. This in consequence supported increased number of vines/plant, number of leaves/plant, length of vines, number of undamaged fruits/plot, number of fruits and fruits weights that was appreciably close to that from water melon crops sprayed with karate, synthetic insecticide used. The performance of these two botanicals can therefore be use as alternative to synthetic insecticides in managing Epilachna beetle.

\section{ACKNOWLEDGEMENTS}

The authors are grateful to Mr. Sadaka Ambi and Yusuf M. For assisting with data collection. We thank Dr. Sodaugi, I. Abbas for assisting with the type setting and analysis of the data.

\section{References}

[1] Alford D.V. (1984). Fruit pests: their recognition, biology and control. Wolfe Ltd. London: pp. 320.

[2] Babarinde S.A., Adebayo M.A. Odeyemi K., African Journal of Biotechnology 7 (2008) 1187-1191

[3] Dabashiri M., Tamal M., Research Journal of Recent Science 1 (2012) 94-99.

[4] Degri M.M., Maina Y.T, Richard B.I., Journal of Biology Agriculture and Healthcare 2 (2012) 46-51.

[5] Degri M.M., Mailafiya D.M., Wabekwa J.W., Advances in Entomology 1(2) (2013) 10-14.

[6] Ghazanfar S.A. (1989). Savannah plants of Africa. Macmillan Ltd, London, pp. 227.

[7] Ghosh G.K. (2010). Bio-pesticides and integrated pest management. African publishers House, Ibadan, pp. 210.

[8] Gupta S.P., Prakash A., Rao J., Journal of Applied Zoological Research 1 (1990) 55-58.

[9] Ibekwe H.N., Nwanguma E.I., Uwalaka O.A., Opara S.C., Ngbede S.O., Onyegbule U., (2013). Evaluation of the efficacy of some plant leaf extracts on insect pest infestation, growth and yield of water melon in Okigwe south-eastern Nigeria. $31^{\text {st }}$ Annual Conference Book of Abstract of HORTSON held at RMRDC, $22^{\text {nd }}-26^{\text {th }}$ September, 2013, pp. 86.

[10] Muhammad S.M., Afolayan S.O., Idris B.A., Gwammaja M.Y., Habu S.H., Yaduma J.J., Bala M.G., Giginya Y.G. (2013). Comparative yield potentials of five varieties of Water melon in the Guinea Savannah Ecological Zone of Kano, Nigeria. $31^{\text {st }}$ Annual 
Conference Book of Abstract of HORTSON held at RMRDC, $22^{\text {nd }}-26^{\text {th }}$ September, 2013, pp. 86.

[11] Nath P., Sundari P., Singh D.P. (2002). Vegetables for the Tropical Region. Indian council of Agricultural Research, New Delhi, pp. 420.

[12] Pareek B.L., Kavandia V.S., Tropical pest management 34(10) (1988) 32-38.

[13] Ratnadass A., Deberdt P., Fernandes P., Grechi I., Rhino B., Rychewaert P., Malezieux E. (2011). An ecologically intensive Approach for the design of sustainable Horticultural congress on science and Horticultural for people. International symposium on August, 2010, Lisbon, Portugal. Pp. 466-467.

[14] Rossel H.H., Thattapilly G. (1985). Pests and Diseases of important Food crops in Africa, Ibadan, Nigeria. International institute of Tropical Agriculture (11TA), pp. 61.

[15] Schippers R.R. (2000). Africa Indigenous vegetables, Chatham, UK, pp. 214.

[16] Shagufta S. (2012). Fruits and vegetables production. African Publishing House, Ibadan, Nigeria, pp. 420.

[17] Siddappaji C., Kumar A.R.V., Gangadhar R., Pesticides 20 (1986) 13-16.

[18] Ullah M., Tropical pest management 33(1) (1987) 8-30.

[19] Van der Vossen H.A.M., Denton O.A., El-Tahir I.M. (2004). Citrullus lanatus (thumb) Matsum and Nakai pp 185-191. In Grubben, G.J.H. and Denton, O.A. (eds). PROTA (plant Resources of Tropical Africa), Wageningen, Netherlands,

[20] White I.M., Harris M., Elson M. (1940). Fruit flies of economic significances. Their Identification and Bionomics. International institute of Entomology, London, UK, pp. 556.

[21] Youdeowei A. (2004). Integrated pest management practices for the production of vegetables. Ministry of Food and Agriculture, Ghana, pp. 49. 